\title{
Letter
}

\section{Vaccination against COVID-19 in the Brazilian indigenous population: Has science been defeated by fake news?}

\author{
Marcelo dos Santos Barbosa ${ }^{[1]}$, Mariana Garcia Croda ${ }^{[2]}$ and Simone Simionatto[ ${ }^{[1]}$
}

\begin{abstract}
[1]. Universidade Federal de Grande Dourados, Laboratório de Pesquisa em Ciências da Saúde, Dourados, MS, Brasil.
\end{abstract}
[2]. Universidade Federal do Mato Grosso do Sul, Faculdade de Medicina, Campo Grande, MS, Brasil.

\section{Dear Editor:}

The COVID-19 pandemic has strongly affected the Brazilian indigenous population, with over 45,000 people infected, an incidence of 5,782 cases $/ 100,000$ people and more than 600 deaths ${ }^{1}$. Despite efforts to contain the spread of this disease, the number of cases continues to increase. The second largest indigenous reserve in the country, which is located in the city of Dourados, Mato Grosso do Sul State, saw 445 new cases in January 2021 among its approximately 18,000 indigenous inhabitants - an incidence of 2,472 cases/100,000 inhabitants in 1 month, which is $14 \%$ higher than the incidence for the entire year of 2020. Among all indigenous people, 753 were diagnosed with COVID-19 in the first trimester of 2021 alone $^{1}$. These findings indicate that massive vaccination of this population is needed to control the disease.

In mid-January 2021, an immunization campaign began among indigenous people over 18 years old-approximately 410,000 people. A comprehensive search of the number of indigenous people vaccinated per unit of the federation (UF) was performed using the vaccination monitoring system of the Brazilian health system. By April 28, only $32.44 \%$ of the total indigenous population $(249,291 / 774,024$ people) and $60.91 \%$ of the adult population $(249,291 / 409,883$ people $)$ had received the booster dose (Figure 1 and Table 1) ${ }^{2}$. Of the 18 states evaluated, six had not vaccinated more than $30 \%$ of the total population with the booster dose, and only two states - Ceará (68\%) and Paraíba (62\%)—had achieved a $60 \%$ vaccination rate among the total indigenous population (Figure 1 and Table 1).

The Indigenous Special Sanitary District (ISSD) of Mato Grosso do Sul hosts the second largest indigenous population in

\footnotetext{
Corresponding author: Simone Simionatto.

e-mail: simonesimionatto@ufgd.edu.br

(D) https://orcid.org/0000-0003-2367-0915

Received 22 May 2021

Accepted 20 July 2021
}

the country $(83,434$ people) (Table 1), and it features villages that are geographically accessible to an urban center ${ }^{3}$. For these reasons, several vaccination sites were created inside this ISSD and, in specific cases, health teams were dispatched to patients' homes. Unfortunately, even with these strategies, the percentage of vaccinated people 2 months later was still below that expected. Prior to April 28, only 35,790 indigenous people had received the first dose of the CoronaVac ${ }^{\mathrm{TM}}$ vaccine in ISSD/MS, which corresponds to $43.3 \%$ of the total population and $78 \%$ of adults. Similarly, 29,613 people had received the booster dose (35.6\% of the total population and $64 \%$ of adults) (Figure 1 and Table 1$)^{2}$. Because the vaccination uptake was low, the unused doses were distributed to other groups of non-indigenous individuals, such as health professionals and the elderly.

In 2019, before the coronavirus pandemic and the flood of anti-vaccine news, only three states had an influenza vaccination coverage below 90\% among the indigenous population (Amapá: 88.93\%, Paraíba: $89.31 \%$, and Mato Grosso do Sul: $82 \%)^{4}$. On the other hand, these states had lower rates of vaccination for COVID-19. In addition, the rates of vaccination in Acre, Roraima, and Santa Catarina states, did not reach $30 \%$ of the total indigenous population (Figure 1 and Table 1) $)^{2}$. The low vaccination uptake among indigenous populations is a public health emergency as it may lead to an increase in the number of cases, especially cases of the new Brazilian SARS-CoV-2 Gamma variant ${ }^{5}$.

The COVID-19 pandemic has exposed the constant social vulnerability of indigenous peoples in Brazil, such as the precariousness of health services, housing conditions, and education $^{6,7}$. This scenario, along with fake news about vaccines, must have contributed to the low vaccine roll-out ${ }^{8,9}$. Many fake news attempts to disparage the vaccine have made false assertions about its effects, claiming that the vaccine contains monitoring chips or that it leads to genetic alterations ${ }^{10}$. The fake news spread on social media, which is the main source of information for indigenous people, has been buttressed by discourse from important Brazilian 


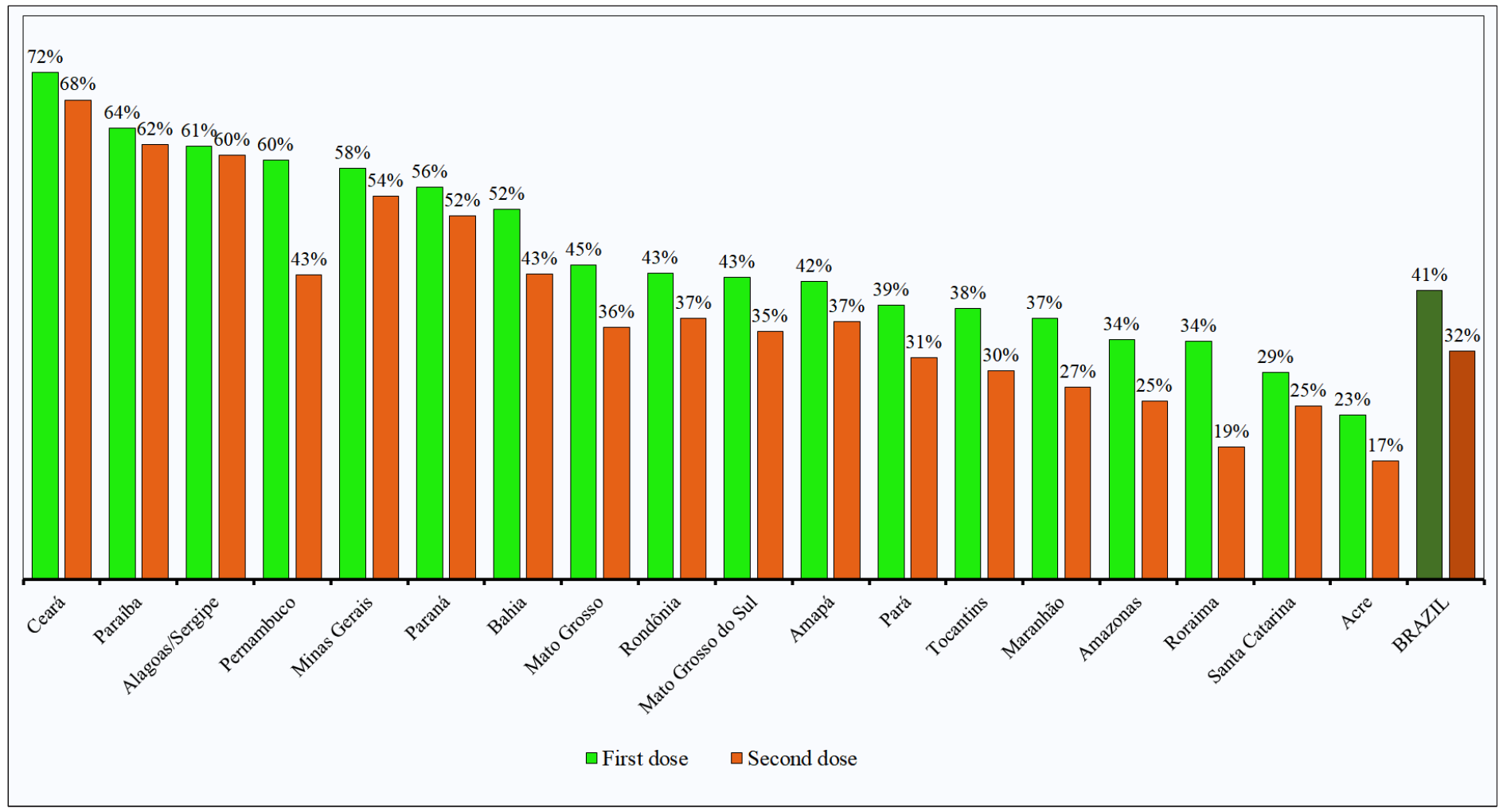

FIGURE 1: Percentage of COVID-19 vaccine doses in the total Brazilian Indigenous population of each Indigenous Special Sanitary District federative headquarters until April 28, 2021.

TABLE 1: Percentage of indigenous adults vaccinated using both doses before April 28, 2021.

\begin{tabular}{|c|c|c|c|c|c|c|}
\hline \multirow{2}{*}{$\begin{array}{c}\text { UF headquarters } \\
\text { ISSD }\end{array}$} & \multicolumn{2}{|c|}{ Population } & \multicolumn{4}{|c|}{ Vaccine in adults } \\
\hline & Total & Adults & First dose & $\%$ & Second dose & $\%$ \\
\hline Ceará & 26,129 & 20,427 & 18,789 & 91,98 & 17,782 & 87,05 \\
\hline Paraíba & 14,024 & 9,931 & 8,976 & 90,38 & 8,662 & 87,22 \\
\hline Alagoas/Sergipe & 12,250 & 8,029 & 7,526 & 93,74 & 7,375 & 91,85 \\
\hline Pernambuco & 39,231 & 26,020 & 23,364 & 89,79 & 16,956 & 65,17 \\
\hline Minas Gerais & 16,684 & 10,230 & 9,742 & 95,23 & 9,070 & 88,66 \\
\hline Paraná & 22,975 & 14,481 & 12,789 & 88,32 & 11,85 & 81,83 \\
\hline Bahia & 29,284 & 20,259 & 15,365 & 75,84 & 12,693 & 62,65 \\
\hline Mato Grosso & 41,120 & 26,326 & 18,342 & 69,67 & 14,704 & 55,85 \\
\hline Rondônia & 17,470 & 8,716 & 7,582 & 86,99 & 6,476 & 74,30 \\
\hline Mato Grosso do Sul & 83,434 & 45,693 & 35,790 & 78,33 & 29,339 & 64,21 \\
\hline Amapá & 12,440 & 7,288 & 5,259 & 72,16 & 4,551 & 62,45 \\
\hline Pará & 36,405 & 22,223 & 14,179 & 63,80 & 11,440 & 51,48 \\
\hline Tocantins & 11,908 & 6,000 & 4,582 & 76,37 & 3,529 & 58,82 \\
\hline Maranhão & 36,060 & 18,708 & 13,375 & 71,49 & 9,822 & 52,50 \\
\hline Amazonas & 196,054 & 93,401 & 66,603 & 71,31 & 49,517 & 53,02 \\
\hline Roraima & 78,699 & 36,072 & 26,581 & 73,69 & 14,790 & 41,00 \\
\hline Santa Catarina & 63,118 & 20,922 & 18,551 & 88,67 & 15,512 & 74,14 \\
\hline Acre & 31,177 & 15,157 & 7,273 & 47,98 & 5,223 & 34,46 \\
\hline BRAZIL & 768,462 & 409,883 & 314,668 & 76,77 & 249,291 & 60,82 \\
\hline
\end{tabular}

UF: Federative Units; ISSD: Indigenous Special Sanitary District. 
politicians ${ }^{11}$. While most world leaders gathered to discuss the vaccine, Brazil, which was once a world example with its National Vaccination Program ${ }^{8}$, saw its leaders discussing and instigating the use of drugs without scientific evidence ${ }^{11,12}$.

Unfortunately, the anti-vaccine rhetoric and misinformation circulated throughout the country also reached Brazilian indigenous reserves, thus discouraging vaccination ${ }^{10}$. In addition, some indigenous deaths at the beginning of the vaccination process caused insecurity within this population, even though the incidents were not associated with SARS-CoV-2 vaccination ${ }^{6}$. These factors, in addition to the ever-present lack of educational material produced in indigenous languages, may have contributed to the low vaccination coverage. In a joint effort, universities and some non-governmental organizations have been producing educational material in native indigenous languages since the beginning of the pandemic, trying to clear doubts about COVID-196. These efforts need to be encouraged by the federal government and health agencies to broaden the amount of correct information about this disease and effective ways to reduce its spread. Higher vaccine uptake, extensive testing, use of masks, social isolation, and hand hygiene need to be intensified to reduce the number of new deaths due to COVID-19 among Brazilian indigenous populations.

\section{ACKNOWLEDGMENTS}

None.

\section{AUTHORS' CONTRIBUTIONS}

All authors contributed equally to the preparation of this work.

\section{CONFLICT OF INTEREST}

The authors declare that there is no conflict of interest.

\section{FINANCIAL SUPPORT}

None.

\section{ORCID}

Marcelo Barbosa: 0000-0001-8059-6630

Mariana Garcia Croda: 0000-0003-1436-9717

Simone Simionatto: 0000-0003-2367-0915

\section{REFERENCES}

1. Ministério da Saúde (MS). Secretaria de Vigilância em Saúde. Sistema Nacional de Vigilância em Saúde. Boletim Epidemiológico COVID-19: Situação dos casos Distrito Sanitário especial Indígena de Mato Grosso do Sul. Brasília: MS; 2021.

2. Ministério da Saúde (MS). Secretaria de Vigilância em Saúde. Sistema Nacional de Vigilância em Saúde. Imunização Indígena: COVID-19. Brasília: MS; 2021.

3. Brasil. Instituto Brasileiro de Geografia e Estatística: Mapa de distribuição da população indígena no Brasil. Brasil: IBGE;2010. https://indigenas.ibge.gov.br/

4. Ministério da Saúde (MS). Secretaria de Vigilância em Saúde. Sistema de Informação do Programa Nacional de Vacinação. Brasil: MS; 2021.

5. Centers for Disease Control and Prevention /CDC. Coronavírus Disease 2019 (COVID-19). Centers for Disease Control and Prevention; 2020.

6. Articulação dos povos indígenas do Brasil/APIB [Internet]. Relatório: Emergência Indígena. APIB; 2021 [updated on May 21, 2021; cited on May 21, 2021]. Available from: https://apiboficial.org/emergenciaindigena/

7. Simionatto S, Barbosa M, Marchioro SB, et al. COVID-19 in Brazilian indigenous people: a new threat to old problems. Rev Soc Bras Med Trop 53:e20200476. doi: 10.1590/0037-8682-0476-2020. Epub 2020 Aug 26. PMID: 32876317; PMCID: PMC7451499.

8. Domingues CMAS, Maranhão AGK, Teixeira AM, et al. 46 anos do Programa Nacional de Imunizações: uma história repleta de conquistas e desafios a serem superados. Cad Saúde Pública 2020;36:e00222919.

9. Instituto Amazonia Real [internet]. Caos na pandemia: Indígenas viram alvo de fake news antivacina. Instituto Amazonia Real; 2021 [updated on April 5, 2021; cited on May 21, 2021]. Available from: https://amazoniareal.com. br/caos-na-pandemia-indigenas-viram-alvo-de-fake-news-antivacina/.

10. Peet C. Aljazira [Internet]. COVID rumours hamper Brazil's efforts to vaccinate Indigenous. Alzajera;2021 [updated on February 18, 2021; cited on May 21, 2021]. Available from: https://www.aljazeera.com/news/2021/2/18/ covid-rumours-hamper-brazils-efforts-to-vaccinate-indigenous.

11. Hallal PC. SOS Brazil: science under attack. The Lancet 2021; 397:373-4.

12. Shalders A. BBC News [Internet]. "Tratamento precoce": governo Bolsonaro gasta quase R\$90 milhões em remédios ineficazes, mas ainda não pagou Butantan por vacinas. BBC News Brasil. 2021 [updated on January 21, 2021; cited on May 21, 2021]. Available from: https:// www.bbc.com/portuguese/brasil-55747043. 